\title{
Uterine blood flow, myometrial activity and their response to adenosine during the peri-implantation period in sheep
}

\author{
I. R. Fleet and R. B. Heap \\ Agricultural Research Council Institute of Animal Physiology, Babraham, \\ Cambridge CB2 4AT, U.K.
}

\begin{abstract}
Summary. Uterine blood flow and myometrial activity were measured simultaneously in anaesthetized sheep 15 days after a sterile (non-pregnant group) or fertile (pregnant) mating. During the peri-implantation period uterine blood flow was similar in both groups of animals, but spontaneous myometrial activity was greatly reduced in pregnant ewes. This 'block' of myometrial activity was associated with circulating levels of progesterone which were significantly higher $(2.8 \pm 0.8 \mathrm{ng} / \mathrm{ml}$, mean \pm s.e.m. $)$ than those in non-pregnant animals $(0.4 \pm 0.3 \mathrm{ng} / \mathrm{ml})$. Adenosine injected into the uterine artery produced uterine vasodilatation in both groups, but the log dose-response was significantly less in pregnant than in non-pregnant animals $(P<0.001)$. Myometrial activity was stimulated by adenosine, particularly in the pregnant group $(P<0.001)$. Vascular and myometrial effects were potentiated by a previous infusion of dipyridamole. Occlusion of the uterine artery produced reactive hyperaemia, and oestradiol infused close-arterially induced vasodilatation after a lag phase of about $30 \mathrm{~min}$. Our results are consistent with a hypothesis that vascular and myometrial cells in the uterus may contain two types of adenosine receptor, one mediating excitatory and the other inhibitory responses, and that both responses are modified by the presence of a conceptus. The results also support the idea that oestrogens produce uterine vasodilatation by increasing the local concentration of vasoactive substances.
\end{abstract}

\section{Introduction}

An embryonic signal that prolongs the life-span of the corpus luteum in sheep is produced before the time of definitive attachment on Day 16 of pregnancy (Moor \& Rowson, 1966; Moor, 1968; Boshier, 1969). This signal results in the continued secretion of progesterone which is essential for the establishment and maintenance of pregnancy. Previous studies have shown that among the biochemical changes that occur in the uterus before implantation are increases in the rate of protein synthesis, in the concentration of prostaglandin (PG) F in caruncular (Findlay et al., 1981) and total (Ellinwood, Nett \& Niswender, 1979) endometrial tissue, and a decrease in the net production of PGF in caruncular tissue (Findlay et al., 1981). Vascular changes evident during this period include a transient increase in uterine blood flow between Days 13 and 15 of pregnancy (Greiss \& Anderson, 1970a), and a diminished vasoconstrictor response of the uterine artery to periarterial sympathetic nerve stimulation (Pope \& Stormshak, 1979).

Oestrogen injections mimic many of these preimplantation changes in ovariectomized and intact animals. Oestradiol increases the rate of protein synthesis and decreases net production of PGF in caruncular tissue (Findlay et al., 1981); it stimulates uterine blood flow when injected 
into the circulation (Greiss \& Anderson, 1970b) or into the uterine lumen (Greiss \& Miller, 1971); and reduces the vasoconstrictor response of the uterine artery to sympathetic nerve stimulation (Ford, Weber \& Stormshak, 1977). However, the production of oestrogens by the sheep conceptus during the peri-implantation period could not be demonstrated (Gadsby, Heap \& Burton, 1980; Heap et al., 1981), though this may be due to an inability to detect a low level of activity rather than a complete absence of oestrogen production.

The purpose of this study was to determine uterine blood flow and spontaneous myometrial activity during the peri-implantation period in pregnant sheep (Day 15 post coitum) compared with that in non-pregnant animals 15 days after oestrus. Adenosine was injected into the uterine artery to demonstrate whether vascular and myometrial cells responded differently in pregnant and non-pregnant animais. This nucleoside was used because it has been proposed that the vasodilatory properties of oestrogens in the uterus of sheep depend on an increased local concentration of vasoactive substances such as adenosine that act as a mediator (Resnik, Killam, Barton, Battaglia, Makowski \& Meschia, 1976; Resnik \& Brink, 1978). Adenosine is a powerful vasodilator in many tissues (Arch \& Newsholme, 1978) and Berne (1980) considers that it has an important role in the regulation of coronary blood flow as a chemical messenger elaborated by the tissue to signal appropriate adjustments.

\section{Materials and Methods}

\section{Animals}

Multiparous Clun Forest ewes were obtained from the Institute's flock. Ovulation was induced by the intramuscular injection of a PGF-2 $\alpha$ analogue (Estrumate: I.C.I. Pharmaceuticals, Alderley Edge, Cheshire) using the procedure described by Acritopoulou, Haresign \& Lamming (1978). Oestrus was detected by mating with an intact or vasectomized ram fitted with a marker, and the day of first marking was designated Day 0. Animals were kept with a vasectomized ram in paddocks adjacent to the laboratory, but on the day before an experiment they were housed indoors and food was withheld overnight. Experiments were carried out on Day 15 and animals were tested for behavioural oestrus with a vasectomized ram immediately before an experiment.

\section{Surgery}

Experiments were carried out using sterile procedures. Anaesthesia was induced with sodium pentobarbitone i.v. (Sagatal: May \& Baker, Dagenham) and initially maintained with halothane (Fluothane: I.C.I. Pharmaceuticals) and oxygen inhalation in a re-breathing closed circuit with $\mathrm{CO}_{2}$ removal by soda lime. Systemic blood pressure was monitored throughout by a pressure transducer connected to a carotid artery catheter. The reproductive tract was located by mid-ventral laparotomy and exposed with the aid of a Devine retractor. A 5-ml two-way Foley catheter was inserted through a small incision in the uterine horn and positioned near the cervix, and inflated with not more than $3 \mathrm{ml}$ air. A polyvinyl catheter (i.d. $1.0 \mathrm{~mm}$, o.d. $1.5 \mathrm{~mm}$ ) was introduced through the utero-tubal junction into the proximal end of the horn and fixed in position by ligatures tied onto a polythene ferrule. Each horn was flushed through the Foley catheter with $20 \mathrm{ml}$ warm sterile saline $(0.9 \%(\mathrm{w} / \mathrm{v}) \mathrm{NaCl})$, and filled with saline to give a resting pressure of about $5-15 \mathrm{mmHg}$.

The middle uterine artery was cannulated with a thin-walled, polished stainless-steel cannula (o.d. $2 \mathrm{~mm}$ ) introduced into the artery after a systemic injection of heparin ( $700 \mathrm{units} / \mathrm{kg}$ body weight). The cannula was connected to silicone rubber tubing, previously filled with heparinized saline (100 units $/ \mathrm{ml})$ and exteriorized through a stab incision in the abdominal wall. An arterial shunt consisting of a siliconized glass T-piece and an electromagnetic square-wave flow probe 
(Devices Flowmeter 3760, Welwyn Garden City, Herts) was established between the uterine artery and a cannulated femoral artery (Pl. 1, Fig. 2). The period of ischaemia was kept as short as possible and rarely exceeded $2 \mathrm{~min}$. Heparinized saline (100 units $/ \mathrm{ml})$ and other solutions were infused into the arterial shunt through the $\mathrm{T}$-piece and anaesthesia was subsequently maintained with sodium pentobarbitone i.v. $(30 \mathrm{mg} / \mathrm{ml})$, the period when blood pressure was depressed by halothane anaesthesia being kept to a minimum. To ensure that the blood supply to the uterine horn was confined to the middle uterine artery, the ipsilateral ovarian artery and vessels in the cervix and mesosalpinx were ligated, and interrupted mattress sutures were placed between the two horns to prevent blood crossing through small vessels. The uterine horn used in each experiment was selected to ensure that the contralateral ovary contained a corpus luteum.

\section{Recordings}

Intrauterine pressure and uterine blood flow were recorded continuously for a period of at least $1.5 \mathrm{~h}$ (control period) before the response to rapid injections of adenosine was determined (test period). Intrauterine pressure recordings were obtained by connecting the fluid-filled Foley catheter to a Bell and Howell fluid-filled pressure transducer and a Devices 4 Channel Recorder, M4. The records were analysed by the method described by Lye \& Porter (1978). They were divided into $10-\mathrm{min}$ sections and analysed for frequency (pressure cycles/10 min) and mean excursion of active pressure cycles $(\mathrm{mmHg})$. Lye \& Porter (1978) defined an active pressure cycle as any increase in pressure of $10 \mathrm{mmHg}$ or more above the resting pressure which was followed by a fall in pressure of $10 \mathrm{mmHg}$ or more. Uterine blood flow was determined by connecting the cannulated electromagnetic flow probe to a Devices Flowmeter 3760 and recordings were made on a 2-channel integrating recorder (Bryans Southern Recorders, Mitcham, Surrey), with a sensitivity of $3 \mathrm{ml} / \mathrm{cm}$ pen deflection. Mean uterine blood flow was calculated by integration.

\section{Calibration of flow probes}

Two blood flow transducers (cannulated type, i.d. $1.5 \mathrm{~mm}$ ) were calibrated. Heparinized blood was perfused through the transducers at flow rates measured by using a stop-watch and graduated cylinder, and the electromagnetic flowmeter reading was noted simultaneously. Text-figure 1 shows that the relationship between actual flow and the meter reading was linear over the range studied.

\section{Test period}

Reactive hyperaemia. Uterine arterial blood flow was occluded for various periods up to 1 min. Reactive hyperaemia was calculated from the increase in uterine blood flow above resting values after occlusion.

Adenosine. Adenosine (BDH, Poole, Dorset) was dissolved in $0.9 \% \mathrm{NaCl}$ to give a concentration of $10-2000 \mu \mathrm{g} / \mathrm{ml}(0.038-7.49 \mathrm{~mm})$. Adenosine in $500 \mu \mathrm{l}$ warm saline (pyrogen-free) was injected rapidly into the femoral-uterine arterial shunt. Control injections consisted of $500 \mu \mathrm{l}$ warm saline. Results were expressed as the maximum amplitude of intrauterine pressure $(\mathrm{mmHg})$ and the change in uterine blood flow $(\Delta \mathrm{ml} / \mathrm{min})$ above resting values.

Oestradiol infusion. An aliquot of a stock solution of oestradiol-17 $\beta$ (Sigma, London) in ethanol was taken to dryness in a glass cylinder and $25 \mathrm{ml}$ autologous plasma were added. The steroid was dissolved in plasma after standing at room temperature for 20 min and $0.9 \% \mathrm{NaCl}$ $(1: 1, \mathrm{v} / \mathrm{v})$ was added to give a final steroid concentration of $5 \mu \mathrm{g} / \mathrm{ml}$. This solution was infused at a constant rate $(0.191 \mathrm{ml} / \mathrm{min}, 0.62 \mu \mathrm{g} / \mathrm{min})$ from a $50 \mathrm{ml}$ glass syringe mounted on an 


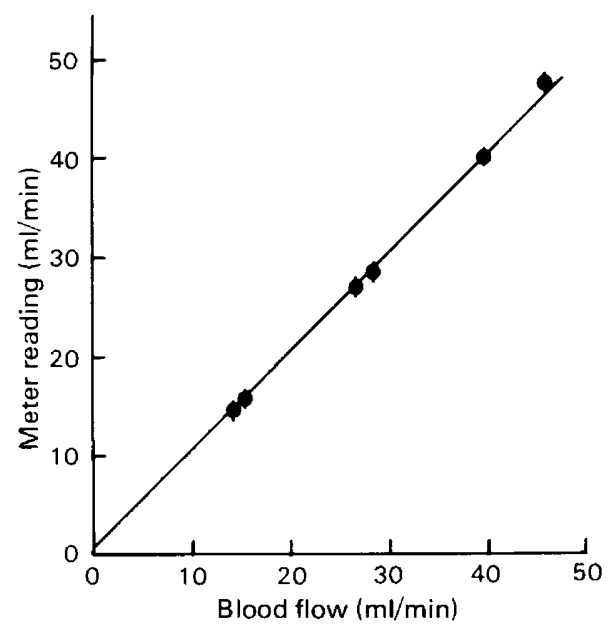

Text-fig. 1. Calibration of two electromagnetic cannulated flow transducers showing a linear relation between actual blood flow and meter reading $(\mathrm{ml} / \mathrm{min}, y=0.969 x+0.619)$. Each point represents the mean ( \pm s.e.m.) of 5 determinations.

infusion pump (Harvard Instrument Co., Massachusetts, U.S.A.). The infusion rate was selected to simulate the maximum production rate of oestradiol-17 $\beta$ in pregnancy (Challis, Harrison \& Heap, 1973).

Dipyridamole infusion. A $10 \mathrm{~mm}$ solution of dipyridamole (an inhibitor of adenosine transport) was prepared in heparinized saline $(100$ units $/ \mathrm{ml})$ and infused at a constant rate $(0.33$ $\mathrm{ml} / \mathrm{min}, 0.06 \mu \mathrm{mol} / \mathrm{min}$ ) from a $20-\mathrm{ml}$ plastic syringe mounted on an infusion pump (Harvard Instrument $\mathrm{Co}$.).

Distribution of blood flow. Radio-opaque barium sulphate (Micropaque, Damancy \& Co., Slough, Bucks) was slowly injected into the uterine arterial shunt at the existing pressure which was monitored by a pressure transducer connected to the T-piece. Radiography was carried out in situ to determine whether the middle uterine artery supplied only the isolated uterine horn. The reproductive tract was removed at the end of the experiment and the isolated uterine horn was weighed.

\section{Radioimmunoassay}

A blood sample was taken from the jugular vein of each animal immediately before anaesthesia. Radioimmunoassay of progesterone was carried out according to the method described by Staples, Fleet \& Heap (1982). The reagents, conditions and validation of the assay have been reported elsewhere (Ricketts, Galil, Ackland, Heap \& Flint, 1980; Staples et al., 1982).

\section{PLATE 1}

Fig. 1. Angiogram of the uterine horn of Ewe K386, in which radio-opaque barium sulphate (Micropaque) was injected into the left middle uterine artery (arrows) at existing arterial pressure after the left uterine horn (LUH) had been isolated and the left uterine artery cannulated by the procedure described in the text. Radiography carried out in situ. The angiogram demonstrates that the middle uterine artery supplied only the isolated horn, and there were no vessels crossing over between the left and right uterine horns (RUH).

Fig. 2. Diagram of the preparation, showing the isolated uterine horn separated by ligatures placed between the two horns. A Foley catheter was introduced at the cervical end and a polyvinyl catheter at the uterotubal end of the isolated horn. The middle uterine artery was connected to a femoral artery by an arterial shunt consisting of a glass T-piece and an electromagnetic square-wave flow probe (E.m. probe). 
Plate 1
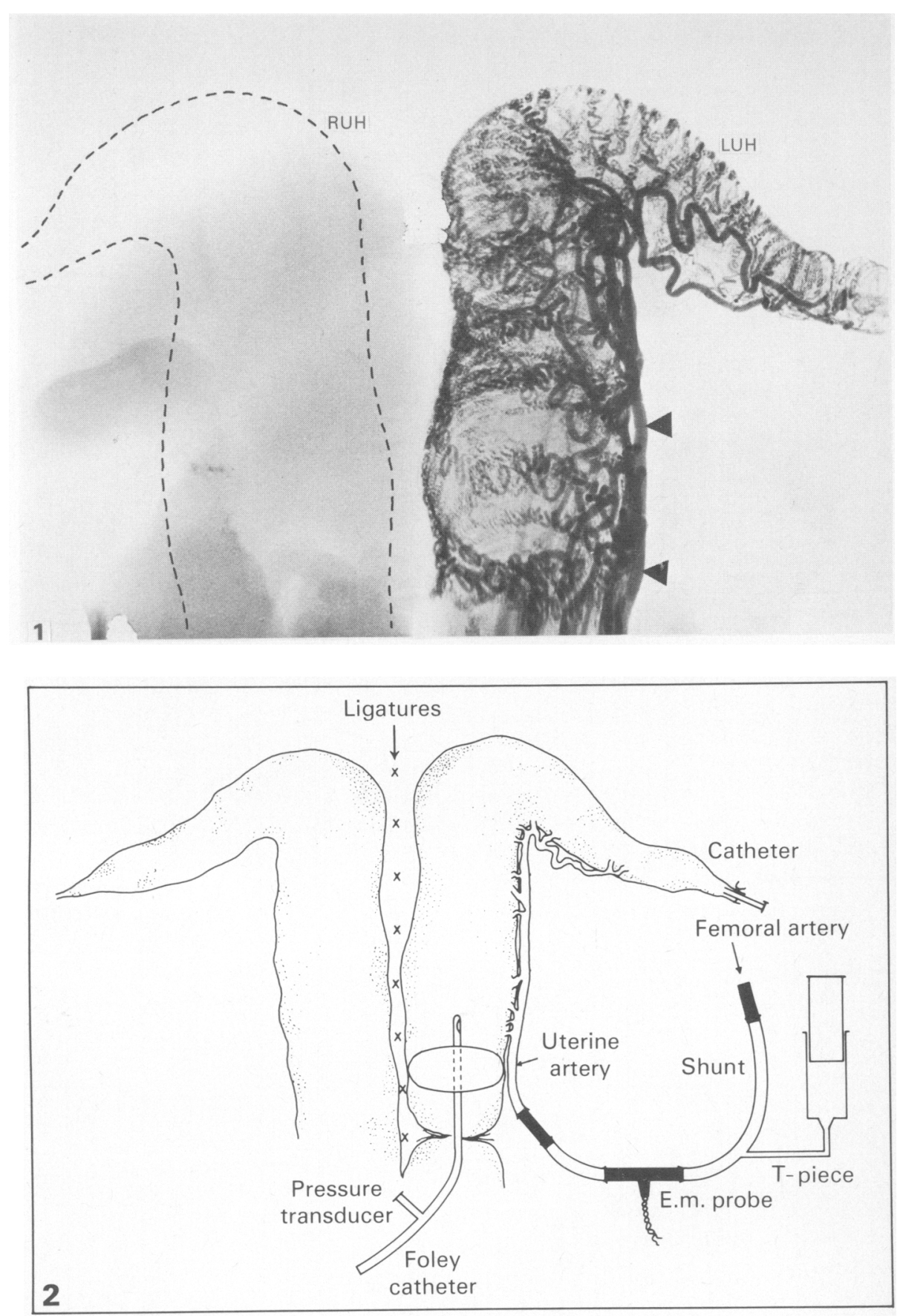

(Facing p. 198) 


\section{Results}

\section{Uterine blood flow and myometrial activity}

Systemic arterial blood pressure varied between 90 and $120 \mathrm{mmHg}$ during the control and experimental periods. Plate 1, Fig. 1 shows that blood flow through the cannulated middle uterine artery was confined to the isolated uterine horn as indicated by the localization of barium sulphate. During the control period, uterine blood flow was similar in pregnant and non-pregnant animals, being $20.0 \pm 3.2$ and $26.3 \pm 2.7 \mathrm{ml} / \mathrm{min}$ (mean \pm s.e.m.) in the two groups, respectively (Table 1). After correction for the weight of the isolated uterine horn the mean flow rate was $94 \pm 10 \mathrm{ml} / \mathrm{min} / 100 \mathrm{~g}$ (mean \pm s.e.m.).

Table 1. Effect of pregnancy on uterine blood flow and myometrial activity measured on the 15th day after oestrus in sheep

\begin{tabular}{lccc}
\hline & Not pregnant & Pregnant & $P$ value* \\
\hline No. of animals & 9 & 6 & - \\
Body weight $(\mathrm{kg})$ & $74.9 \pm 5.0$ & $66.9 \pm 3.4$ & n.s. \\
Wt of isolated horn $(\mathrm{g}) \dagger$ & $35.7 \pm 8.6$ & $21.5 \pm 1.3$ & n.s. \\
Plasma progesterone $(\mathrm{ng} / \mathrm{ml})$ & $0.4 \pm 0.3(6)$ & $2.8 \pm 0.8$ & $<0.02$ \\
Uterine blood flow $(\mathrm{ml} / \mathrm{min})$ & $26.3 \pm 2.7$ & $20.0 \pm 3.2$ & n.s. \\
Uterine contractions & & & \\
$\quad$ Frequency (pressure cycle/10 min) & $30.9 \pm 6.5$ & $<1$ & $<0.01$ \\
$\quad$ Mean amplitude $(\mathrm{mmHg})$ & $29.3 \pm 3 \cdot 1$ & $7.3 \pm 0.8$ & $<0.001$ \\
\hline
\end{tabular}

* Student's $t$ test.

† See text.

The spontaneous myometrial activity was greatly reduced in pregnant compared with non-pregnant animals (Table 1). The frequency of active pressure cycles in pregnant ewes $(<1 \cdot 0$ per $10 \mathrm{~min})$ was significantly less than that found in non-pregnant animals $(30.9 \pm 6 \cdot 5$; Text-figs $2 \mathrm{a}$ and $\mathrm{b}$ and Table 1). Similarly, the mean amplitude of contraction was reduced significantly on Day 15 of pregnancy. This reduction of myometrial activity was associated with a progesterone
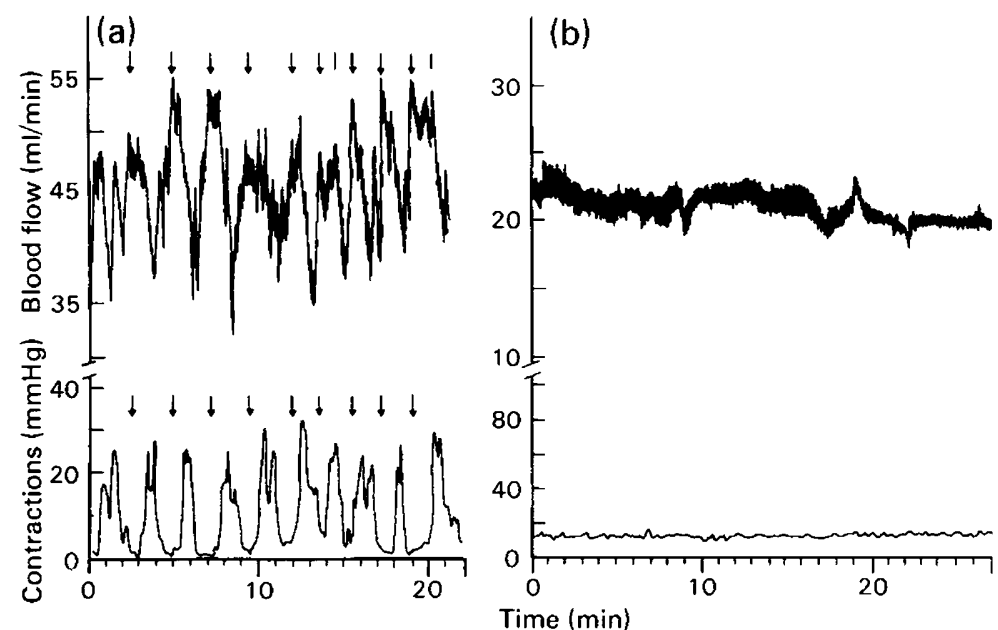

Text-fig. 2. Uterine blood flow and spontaneous myometrial contractions in (a) a non-pregnant ewe (J478) and (b) a pregnant ewe (J419) on Day 15 after a sterile or fertile mating, respectively. Arrows denote when peaks of uterine blood flow coincide with myometrial relaxation. However, this inverse relationship was not invariable since peaks in uterine blood flow occasionally coincided with myometrial contractions (vertical lines). The results show a marked inhibition of myometrial contractions in pregnancy. 
concentration in peripheral plasma which was significantly higher in pregnant compared with non-pregnant animals (Table 1).

In 4 of 9 non-pregnant sheep behavioural oestrus was detected on the morning of Day 15, reflecting the individual variation which occurs in the length of the normal oestrous cycle. In these four animals uterine blood flow $(22.1 \pm 3.1 \mathrm{ml} / \mathrm{min})$ was similar to that in the remaining 5 ewes which were not in oestrus $(29.7 \pm 3.7 \mathrm{ml} / \mathrm{min})$. Active pressure cycles $(24.3 \pm 8.6$ and $36.0 \pm 9.8$ cycles $/ 10$ min respectively) and the amplitude of myometrial contractions $(30.8 \pm$ 3.3 and $28.2 \pm 5.2 \mathrm{mmHg}$ respectively) were also not significantly different and the data were therefore combined for presentation in Table 1.

An inverse relation between uterine blood flow and intrauterine pressure was frequently observed in non-pregnant animals (e.g. Ewe J478) but this was not found in pregnant animals because of the infrequency of contractions (e.g. Ewe J419, Text-fig. 2b). Uterine blood flow was higher in Ewe J478 than in any other animal studied and it was related to an unusually large, but healthy, uterus.

\section{Effect of adenosine}

In the test period, uterine blood flow and the amplitude of myometrial contraction responded to increasing doses of adenosine (Text-fig. 3). Adenosine had a smaller effect on uterine blood flow in pregnant, than in non-pregnant animals $(P<0.001$; Text-fig. 4a). The maximal efficacy estimated from hyperbolic plots of response against log-dose was 31 and $12.5 \mu \mathrm{g}(0.12$ and 0.05 $\mu \mathrm{mol})$ in non-pregnant and pregnant animals, respectively, although the median effective dose $\left(E_{50}\right)$ was similar in the two groups ( 24 and $26 \mu \mathrm{g}, 0.09$ and $\left.0.10 \mu \mathrm{mol}\right)$.

In contrast, adenosine stimulated myometrial contraction to a greater extent in pregnant than non-pregnant animals, mainly because in the latter group spontaneous activity was already considerable (Text-fig. 4b). The slope of the log dose-response was greater in pregnant than in non-pregnant animals, but the difference was not significant statistically because of the variation between individual animals in the non-pregnant group. Maximal efficacy was 50 and $43 \mu \mathrm{g}(0 \cdot 19$ and $0.16 \mu \mathrm{mol}$ ) in non-pregnant and pregnant animals, respectively.

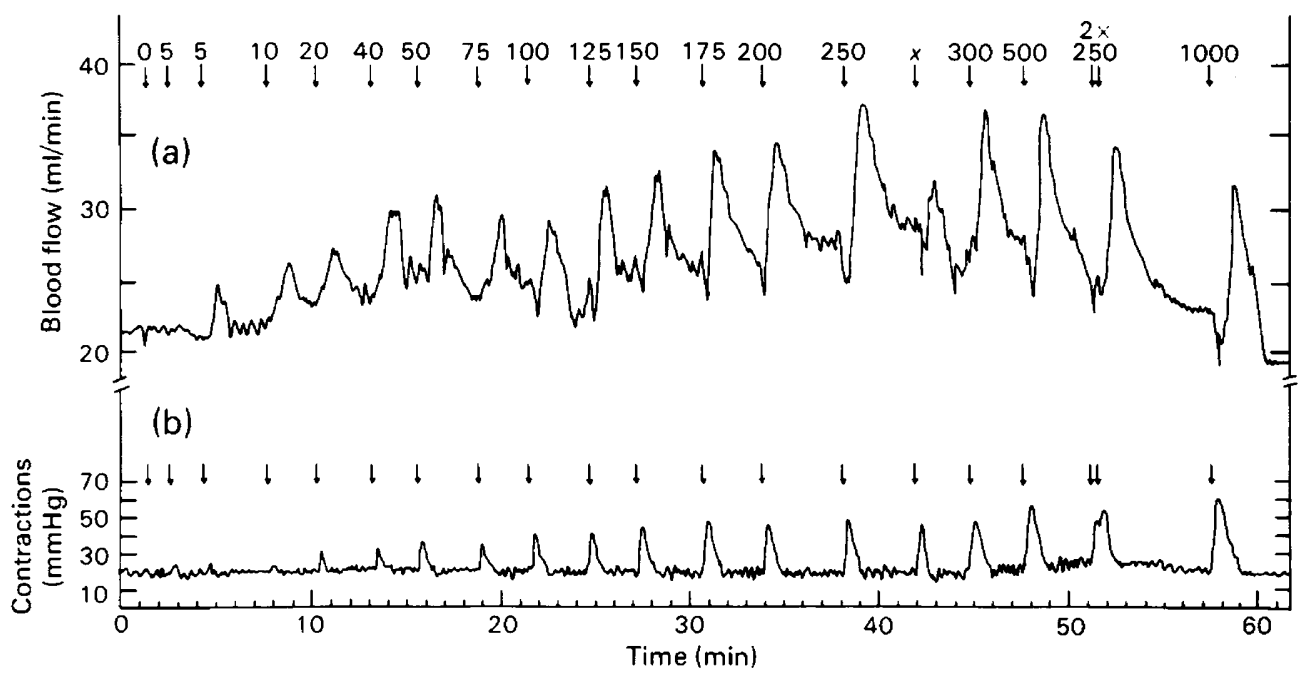

Text-fig. 3. Effect of adenosine on (a) uterine blood flow and (b) myometrial contractions in a pregnant ewe (J299) on Day 15 of gestation. Doses of adenosine ranged from 5 to $1000 \mu \mathrm{g}$ $(0.019$ to $3.745 \mu \mathrm{mol})$. Double arrows, $2 \times 250 \mu \mathrm{g}$; inaccurate injection, $x$. 


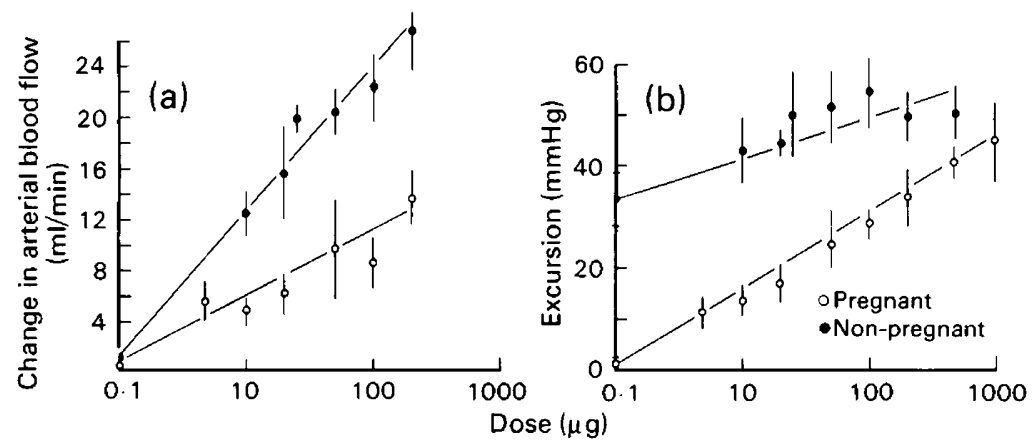

Text-fig. 4. Logarithmic dose-response lines of (a) uterine blood flow and (b) myometrial contractions to adenosine injected into the uterine artery of non-pregnant $(0)$ and pregnant $(0)$ sheep on Day 15 after a sterile or fertile mating, respectively. Values are given as mean \pm s.e.m. for 3-9 animals tested at each dose level. The regression equations for the uterine blood flow response were $y=0.75+5.232 x(P<0.001$, non-pregnant $)$ and $y=0.70+2.155 x(P<$ 0.001 , pregnant animals); pooled regression analysis demonstrated a highly significant difference between the two groups $(P<0.001)$. The regression equations for myometrial contractions were $y=32.2+3.317 x(P<0.05$, non-pregnant $)$ and $y=1.8+6.255 x(P<0.001$, pregnant animals); a significant difference between the two groups could not be demonstrated.

Infusion of adenosine into the uterine lumen of Ewe $\mathrm{J} 493$ at oestrus $(11 \mu \mathrm{g} / \mathrm{min}(0.04$ $\mu \mathrm{mol} / \mathrm{min}$ ) for $20 \mathrm{~min}$ ) increased blood flow from 22.5 to $36 \mathrm{ml} / \mathrm{min}$ within $10 \mathrm{~min}$, but had a negligible effect on myometrial activity.

\section{Effect of oestrogen and dipyridamole}

Oestradiol. To test whether adenosine stimulated uterine blood flow and myometrial contraction after oestrogen-induced vasodilatation, oestradiol-17 $\beta$ was infused into the uterine artery of 2 non-pregnant sheep. Uterine blood flow increased 175 and $188 \%$ after a lag phase of about $30 \mathrm{~min}$; the amplitude of myometrial contractions was unchanged. Adenosine injected close-arterially at doses of up to $400 \mu \mathrm{g}(1.5 \mu \mathrm{mol})$ produced no additional increase in uterine blood flow, whereas before oestradiol infusion $400 \mu \mathrm{g}$ adenosine increased blood flow by $175 \%$ and $206 \%$ in the 2 animals. After infusion of oestradiol, adenosine at doses of up to $400 \mu \mathrm{g}$ increased myometrial contraction in both experiments by 4 and $17 \mathrm{mmHg}$. The comparable values before oestradiol infusion were 17 and $28 \mathrm{mmHg}$, respectively.

Dipyridamole infusion. Infusion of dipyridamole close-arterially for about 10 min enhanced the effect of adenosine on myometrial contractions and uterine blood flow in non-pregnant animals. Both the amplitude and frequency of myometrial activity was increased, and the duration of the blood flow increase was prolonged about 10-fold (Text-fig. 5).

\section{Reactive hyperaemia}

Occlusion of the uterine artery in Ewe K289 (not pregnant) for $0.17,0.33,0.5,0.75$ and 1 min produced a reactive hyperaemia of $10,20,25,30$ and $30 \mathrm{ml} / \mathrm{min}$, respectively. Values in a further 3 non-pregnant ewes after clamping for $0.5 \mathrm{~min}$ were $6.7 \pm 1.2$ and in one pregnant animal, $0.9 \mathrm{ml} / \mathrm{min}$. Reactive hyperaemia was not observed in a ewe tested at oestrus, or in Ewe K289 after infusion of oestradiol-17 $\beta$. When reactive hyperaemia occurred, uterine contractions were suppressed for a period of about $30 \mathrm{sec}$. 


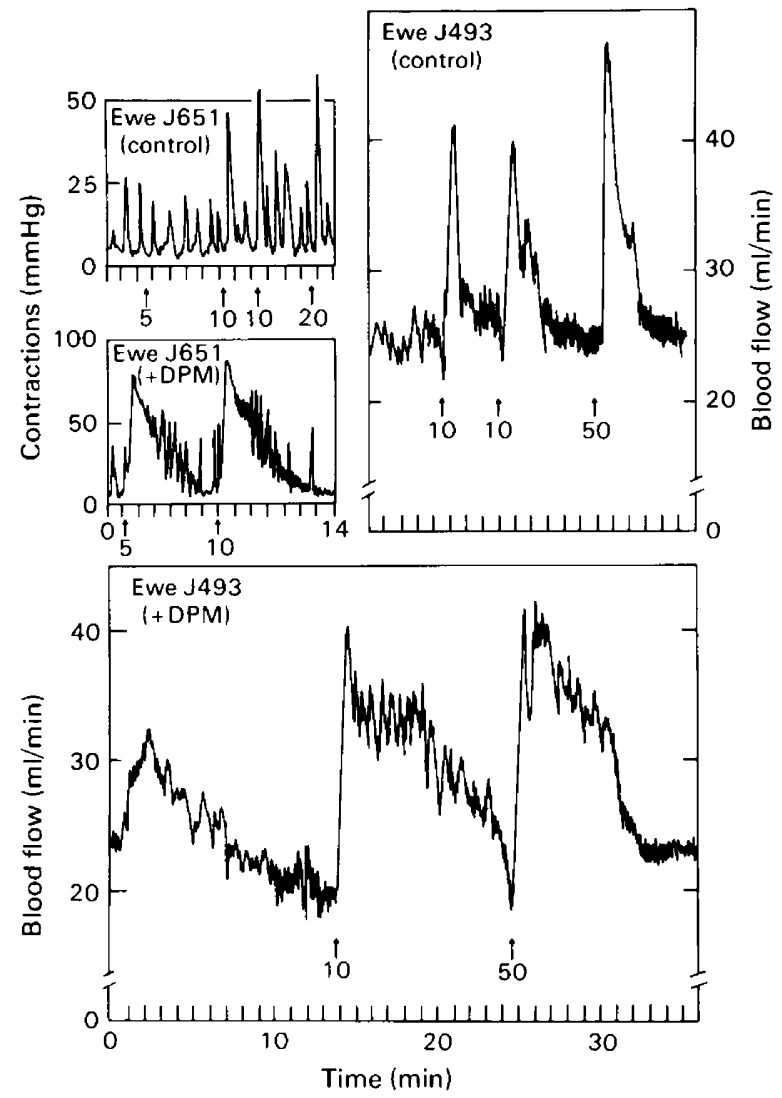

Text-fig. 5. Effect of dipyridamole infusion $(0.06 \mu \mathrm{mol} / \mathrm{min})$ on adenosine-induced vasodilatation and myometrial contractions in two non-pregnant animals at Day 15 after a sterile mating. Tracings show potentiated responses to 5-50 $\mu \mathrm{g}(0.019-0.187 \mu \mathrm{mol})$ adenosine (arrows) after dipyridamole (DPM) infusion.

\section{Discussion}

Spontaneous myometrial activity was markedly suppressed on Day 15 after a fertile mating compared with that in non-pregnant sheep at a comparable time after a sterile mating, whereas uterine blood flow was similar in the two groups of animals. These physiological changes occurred before the time when the conceptus was firmly attached to the caruncular epithelium (Boshier, 1969), though recent studies indicate that trophectoderm papillae have already protruded into intercaruncular glandular openings by Day 15 post coitum (Guillomot, Fléchon \& Wintenberger-Torrès, 1981; Wooding, Staples \& Peacock, 1981). The inhibition of spontaneous myometrial activity in this peri-implantation period resembled the classic progesterone 'block' described by Csapo $(1956,1977)$, and the frequency and amplitude of contractions were very similar to those obtained by Lye \& Porter (1978) after oestrogen-treated ovariectomized ewes with chronically implanted intrauterine balloons were given progesterone. Inhibition of activity was associated with a progesterone concentration in peripheral plasma typical of that found in sheep with a functional corpus luteum whereas in non-pregnant animals, with low progesterone levels, myometrial activity was pronounced and resembled that reported by Lye \& Porter (1978) in oestrogen-treated ovariectomized animals. Therefore, the myometrium appears to respond similarly to a sustained circulating level of progesterone in 
pregnant animals and in ovariectomized animals treated with ovarian steroids, and the results appear to be unaffected by surgery and anaesthesia.

A reduction in spontaneous myometrial activity might be expected by Day 15 of gestation to allow for attachment and implantation, but the precise time when the inhibition first occurs remains to be discovered. The results of Lye \& Porter (1978) suggest that the progesterone 'block' may begin as early as Day 8-10 after oestrus with the establishment of a functional corpus luteum. In polytocous species the disposition of blastocysts within the uterus is probably accomplished by the mechanical activity of the uterus (McLaren \& Michie, 1959; Pusey, Kelly, Bradshaw \& Porter, 1980), and Böving (1956) has suggested that the blastocysts themselves stimulate local myometrial activity and facilitate spacing. We found that adenosine stimulated myometrial contractions when injected into a uterine artery but was ineffective when infused into the uterine lumen, and Findlay et al. (1981) also failed to detect any significant biochemical changes in the myometrium which were associated with the presence of a conceptus on Day 15.

The finding that uterine blood flow on Day 15 was unaffected by pregnancy differs from previous observations, though it is consistent with the failure to demonstrate aromatase activity in the conceptus at this stage (Heap et al., 1981). Greiss \& Anderson (1970a) reported small and transient increases in blood flow on Days 13-15 of pregnancy in 5 of 11 ewes, and Pope \& Stormshak (1979) published in-vitro evidence that the presence of a conceptus produced uterine vasodilatation on Day 13. Transient increases in uterine blood flow have been recorded in the preimplantation period of other domestic animals (cows: Ford, Chenault \& Echternkamp, 1979; pigs: Ford \& Christenson, 1979), particularly in the uterine horn occupied by a conceptus, and these increases have been correlated with oestrogen production by the early embryo. Short-term changes in uterine blood flow would not have been detected readily in the present study, but the flow rates in pregnant (4-fold) and non-pregnant $(0 \cdot 5$-fold) animals were considerably higher than the values obtained by Greiss \& Anderson (1970a) in ewes with chronically implanted flow probes and warrant further consideration.

The oestrogen-induced vasodilatation observed in our studies was similar to that reported by Nuwayhid, Brinkman, Woods, Martinek \& Assali (1975) in intact, normotensive, non-pregnant sheep with chronically-implanted flow probes. However, Killam, Rosenfeld, Battaglia, Makowski \& Meschia (1973) found that surgery and anaesthesia suppressed oestrogen-induced vasodilatation in ovariectomized ewes. The magnitude of oestrogen-induced vasodilatation in chronic preparations is clearly much greater in ovariectomized (Killam et al., 1973; Resnik, Killam, Battaglia, Makowski \& Meschia, 1974; Resnik, Battaglia, Makowski \& Meschia, 1975; Resnik \& Brink, 1978, 1980) than in intact animals (Nuwayhid et al., 1975; present results), probably due to differences in tissue sensitivity resulting from endogenous steroid depletion and subsequent stimulation by repeated injections of oestradiol. Thus, the high flow observed in our study in pregnant animals cannot be attributed to anaesthesia, though it may be related to a reduction in sympathetic vascular tone arising from the procedure of confining flow to the middle uterine artery (Ladner, Brinkman, Weston \& Assali, 1970; Bell, 1972). This procedure may also result in a redistribution of the arterial supply to the pregnant uterus if blood flow through the middle uterine artery is normally supplemented by that of the caudal uterine artery. In this event flow transducers placed chronically on the middle uterine artery would fail to record total blood flow to the uterine horn in early pregnancy.

Adenosine stimulated the contraction of myometrial cells and the relaxation of vascular cells in the sheep uterus, and the effects were modified by pregnancy. Barsoum \& Gaddum (1935) first reported that adenosine caused uterine contraction in the guinea-pig, and Resnik et al. (1976) and Still \& Greiss (1978) investigated its effect on uterine tone and vasodilatation in sheep. In our studies we confirmed that uterine vasculature is highly sensitive to adenosine, the maximal efficacy of the drug being about $0.1 \mu \mathrm{mol}$ for a single close-arterial injection. However, the vasodilatory response to adenosine was markedly reduced in early pregnancy. Ford et al. (1977) found that progesterone enhanced the uterine vasoconstriction produced by nerve 
stimulation in vitro. They suggested that progesterone may cause an increase in the noradrenaline content of peri-arterial sympathetic nerves and influence $\alpha$-adrenergic receptors. However, from the results of our studies in vivo it seems that sustained levels of progesterone in the circulation failed to affect uterine blood flow significantly since values were similar in pregnant and non-pregnant animals on Day 15. It appears, therefore, that progesterone has a negligible effect on the resting value of uterine blood flow at this stage. Further evidence for the involvement of adenosine as a mediator of uterine vasodilatation was provided by the reactive hyperaemia produced by vascular occlusion, a procedure known to enhance adenosine concentrations in several tissues (Arch \& Newsholme, 1978; Berne, 1980). Whether oestrogen-induced vasodilatation results from increased levels of the same vasoactive mediator is not known, but the failure of adenosine to enhance blood flow further after oestradiol infusion supports this idea. However, several other compounds are potent vasodilators in the uterus including certain nucleotides, bradykinin and prostanoids (Resnik et al., 1976; Resnik \& Brink, 1978; Still \& Greiss, 1978), and local synthesis of such compounds may also contribute to the regulation of vascular response.

The influence of adenosine on myometrial activity seemed to differ from the action of oxytocin. Adenosine stimulated contraction when spontaneous activity was inhibited, as in pregnancy, whereas oxytocin was relatively ineffective (Lye \& Porter, 1978). Adenosine-induced contractions in pregnant animals were similar in amplitude and duration to spontaneous contractions in non-pregnant animals, and could be potentiated by dipyridamole infusion which reduces adenosine transport. Adenosine receptors are presumably still present in the quiescent myometrium during early pregnancy in view of this potentiation, but further studies are required to examine whether the classic progesterone 'block' of spontaneous activity results from a suppression of nucleoside synthesis and release. Our results are consistent with the hypothesis that there are two types of adenosine receptor in smooth muscle cells of the uterus, one mediating excitation (myometrial cells) and the other inhibitory responses (vascular cells) (see Arch \& Newsholme, 1978).

We thank colleagues for their help and advice, and in particular Dr Ann Silver, Dr Felicity Maule Walker, Dr J. L. Gordon, Dr J. Pearson, Dr A. P. F. Flint, Mr D. E. Walters and Mr A. L. Gallup.

\section{References}

Acritopoulou, S., Haresign, W. \& Lamming, G.E. (1978) Time of ovulation in ewes after treatment with a prostaglandin F-2 $\alpha$ analogue. J. Reprod. Fert. 54, 189-191.

Arch, J.R.S. \& Newsholme, E.A. (1978) The control of the metabolism and the hormonal role of adenosine. Essays in Biochemistry 14, 82-123.

Barsoum, G.S. \& Gaddum, J.H. (1935) The pharmacological estimation of adenosine and histamine in blood. J. Physiol., Lond. 85, 1-14.

Bell, C. (1972) Autonomic nervous control of reproduction: circulatory and other factors. Pharmac. Rev. 24, 657-736.

Berne, R.M. (1980) The role of adenosine in the regulation of coronary blood flow. Circ. Res. 47, 807-813.

Boshier, D.P. (1969) A histological and histochemical examination of implantation and early placentome formation in sheep. J. Reprod. Fert. 19, 51-61.

Böving, B.G. (1956) Rabbit blastocyst distribution. Am. J. Anat. 98, 403-434.
Challis, J.R.G., Harrison, F.A \& Heap, R.B. (1973) The metabolic clearance rate, production rate and conversion ratios of oestrone in the sheep. J. Endocr. 58, $435-446$.

Csapo, A.I. (1956) Progesterone block. Am. J. Anat. 98, 273-291.

Csapo, A.I. (1977) The 'see-saw' theory of parturition. In The Fetus and Birth (Ciba Fdn Symp. No. 47), pp. 159-210. Eds J. Knight \& M. O'Connor. Excerpta Medica, Amsterdam.

Ellinwood, W.E., Nett, T.M. \& Niswender, G.D. (1979) Maintenance of the corpus luteum of early pregnancy in the ewe. II. Prostaglandin secretion by the endometrium in vitro and in vivo. Biol. Reprod. 21, $845-856$.

Findlay, J.K., Ackland, N., Burton, R.D., Davis, A.J., Maule Walker, F.M., Walters, D.E. \& Heap, R.B. (1981) Protein, prostaglandin and steroid synthesis in caruncular and intercaruncular endometrium of sheep before implantation. J. Reprod. Fert. 62, 361-377. 
Ford, S.P. \& Christenson, R.K. (1979) Blood flow to uteri of sows during the estrous cycle and early pregnancy: local effect of the conceptus on the uterine blood supply. Biol. Reprod. 21, 617-624.

Ford, S.P., Weber, L.J. \& Stormshak, F. (1977) Role of estradiol- $17 \beta$ and progesterone in regulating constriction of ovine uterine arteries. Biol. Reprod. 17, 480-483.

Ford, S.P., Chenault, J.R. \& Echternkamp, S.E. (1979) Uterine blood flow of cows during the oestrous cycle and early pregnancy: effect of the conceptus on the uterine blood supply. J. Reprod. Fert. 56, 55-62.

Gadsby, J.E., Heap, R.B. \& Burton, R.D. (1980) Oestrogen production by blastocyst and early embryonic tissue of various species. J. Reprod. Fert. 60 , 409-417.

Greiss, F.C. \& Anderson, S.G. (1970a) Uterine blood flow during early ovine pregnancy. Am. J. Obstet. Gynec. 106, 30-38.

Greiss, F.C. \& Anderson, S.G. (1970b) Effect of ovarian hormones on the uterine vascular bed. Am.J. Obstet. Gynec. 107, 829-836.

Greiss, F.C. \& Miller, H.B. (1971) Unilateral control of uterine blood flow in the ewe. Am. J. Obstet. Gynec. 111, 299-301.

Guillomot, M., Fléchon, J.-E. \& Wintenberger-Torrès, S. (1981) Conceptus attachment in the ewe: an ultrastructural study. Placenta 2, 169-182.

Heap, R.B., Flint, A.P.F., Hartmann, P.E., Gadsby, J.E., Staples, L.D., Ackland, N. \& Hamon, M. (1981) Oestrogen production in early pregnancy. $J$. Endocr. 89, 77P-94P.

Killam, A.P., Rosenfeld, C.R., Battaglia, F.C., Makowski, E.L. \& Meschia, G. (1973) Effects of estrogens on the uterine blood flow of oophorectomized ewes. Am. J. Obstet. Gynec. 115, 10451052.

Ladner, C., Brinkman, C.R., III, Weston, P. \& Assali, N.S. (1970) Dynamics of uterine circulation in pregnant and nonpregnant sheep. Am. J. Physiol. 218, 257-263.

Lye, S.J. \& Porter, D.G. (1978) Demonstration that progesterone 'blocks' uterine activity in the ewe in vivo by a direct action on the myometrium. $J$. Reprod. Fert. 52, 87-94.

McLaren, A. \& Michie, D. (1959) Superpregnancy in the mouse. I. Implantation and foetal mortality after induced superovulation in females of various ages. $J$. exp. Biol. 26, 281-300.

Moor, R.M. (1968) Effect of embryo on corpus luteum function. J. Anim. Sci. 27, 97-116.
Moor, R.M. \& Rowson, L.E.A. (1966) The corpus luteum of the sheep: effect of removal of embryos on luteal function. J. Endocr. 34, 497-502.

Nuwayhid, B., Brinkman, C.R., Woods, J.R., Martinek, H. \& Assali, N.S. (1975) Effects of estrogens on systemic and regional circulations in normal and renal hypertensive sheep. Am. J. Obstet. Gynec. 123, 495-504.

Pope, W.F. \& Stormshak, F. (1979) Effect of the ovine conceptus on in vitro responses of uterine arteries to prostaglandin $\mathrm{E}_{2}$ and norepinephrine. Biol. Reprod. $20,847-851$.

Pusey, J., Kelly, W.A., Bradshaw, J.M.C. \& Porter, D.G. (1980) Myometrial activity and the distribution of blastocysts in the uterus of the rat: interference by relaxin. Biol. Reprod. 23, 394-397.

Resnik, R. \& Brink, G.W. (1978) Effects of prostaglandins $E_{1}, E_{2}$ and $F_{2 \alpha}$ on uterine blood flow in nonpregnant sheep. Am. J. Physiol. 234, 557-561.

Resnik, R. \& Brink, G.W. (1980) Uterine vascular response to prostacyclin in nonpregnant sheep. $\mathrm{Am}$. J. Obstet. Gynecol. 137, 267-269.

Resnik, R., Killam, A.P., Battaglia, F.C., Makowski, E.L. \& Meschia, G. (1974) The stimulation of uterine blood flow by various estrogens. Endocrinology, 94, 1192-1196.

Resnik, R., Battaglia, F.C., Makowski, E.L. \& Meschia, G. (1975) The effect of actinomycin D on estrogeninduced uterine blood flow. Am. J. Obstet. Gynec. 122, 273-277.

Resnik, R., Killam, A.P., Barton, M.D., Battaglia, F.C., Makowski, E.L. \& Meschia, G. (1976) The effect of various vasoactive compounds upon the uterine vascular bed. Am. J. Obstet. Gynec. 125, 201-206.

Ricketts, A.P., Galil, A.K.A., Ackland, N., Heap, R.B. \& Flint, A.P.F. (1980) Activation by corticosterone of steroid metabolizing enzymes in ovine placental explants in vitro. J. Endocr. 85, 457-469.

Staples, L.D., Fleet, I.R. \& Heap, R.B. (1982) Anatomy of the utero-ovarian lymphatic network and the composition of afferent lymph in relation to the establishment of pregnancy in the sheep and goat. J. Reprod. Fert. 65, 409-420.

Still, J.G. \& Greiss, F.C. (1978) The effect of prostaglandins and other vasoactive substances on uterine blood flow and myometrial activity. Am. J. Obstet. Gynec. 130, 1-8.

Wooding, F.B.P., Staples, L.D. \& Peacock, M.A. (1981) Structure of trophoblast papillae on the sheep conceptus at implantation. J. Anat. (in press). 